\title{
KANDUNGAN KATEKIN GAMBIR SENTRA PRODUKSI DI INDONESIA
}

\author{
Amos \\ Pusat Pengkajian Teknologi Agroindustri \\ Badan Pengkajian dan Penerapan Teknologi \\ Gd 2 BPPT It. $17 \mathrm{Jl}$. MH. Thamrin 8 Jakarta 10340
}

Diajukan: 18 Mei 2010; Dinilaikan: 14 Juni 2010; Diterima: 13 Oktober 2010

\begin{abstract}
Abstrak
Kemandirian peralatan utama sistem persenjataan (alutsista) pertahanan dan keamanan (hankam) dalam menghadapi kemungkinan darurat perang akibat diembargo mutlak dilakukan, termasuk dalam bahan pelat munisi buatan dalam negeri untuk munisi kaliber kecil 5,56 mm khususnya tipe kode Pindad MU 5TJ sebagai peluru yang paling banyak digunakan di pasukan TNI, satu paket dengan senjata senapan serbu SS1. Percobaan dilakukan terhadap pelat kuningan munisi kaliber $5,56 \mathrm{~mm}$ mengikuti persyaratan standar perusahaan yang mengacu pada standar NATO SS 109. Bahan baku: Kawat tembaga super, Zinc Ingot SHG, Nikel Screen, Posphor copper, dan pelat Alumunium. Peleburan tanpa Al sebanyak $80 \mathrm{~kg}$ (4 Slab), dan peleburan $+\mathrm{Al}$ sebanyak $160 \mathrm{Kg}$ (7 Slab). Hasil karakterisasi uji coba pembuatan pelat kuningan (Cu-Zn 70-30) - Komposisi kimia slab: kandungan kimia $\mathrm{Cu}$ masih dalam rentang standar Perusahaan, demikian pula unsur $\mathrm{Pb}, \mathrm{Fe}, \mathrm{Ni}, \mathrm{P}$, $\mathrm{Sb}$, dan Sn masih berada di bawah ambang batas standar perusahaan. Percobaan lain yang dilakukan adalah uji pengerolan, pengamatan metalografi (mikro-struktur) pelat kuningan, pengujian kekerasan pelat kuningan, dan pengujian anil pelat kuningan yang kesemuanya secara umum telah memenuhi persyaratan standar perusahaan yang mengacu pada standar NATO SS 109. Biaya produksi pelat kuningan per $\mathrm{kg}=\mathrm{Rp} 55,838.000 / 160 \mathrm{~kg}=\mathrm{Rp}$ 348,987.5, atau Biaya produksi pelat kuningan per lembar= Rp 55,838.000/11 lembar= Rp 5,076,181.8 yang tentunya akan lebih rendah harga dibanding produk impor, karena tidak termasuk biaya transpor dan asuransi dari luar negeri.
\end{abstract}

Kata kunci: Katekin, SNI, Thrope and Whiteley, Riau, Sumut, Sumsel, Sumbar, Aceh, Babel

\section{Abstract}

\section{Catechin Content of Gambier, Production Centre Indonesia}

Chemical composition of Gambier (Uncaria gambir Roxb.) referring to research done by Thorpe and Whiteley's (1921) consist of main chemical of catechin (7-33\%) and catechu tannat acid (20-55\%). Overall gambier consists of following chemicals, catechin 7-33\%, catechu tannat acid 20-55\%, pyrocatechol 20-30\%, gambier fluoresensi 1-3\%, red catechu 3-5\%, quersetin 2-4\%, fixed oil 1-2\%, wax 1-2\%, and a little trace of alkaloid. Burkill (1935) referred to Thorpe and Whiteley's research (1921), Nazir (2000) as well as Amos et al (2004) also referred to chemical content composition of Thorpe and Whiteley's research (1921), Based on the research done on several Gambier products processed by communities in several Gambier production center region in Indonesia, the content of catechin varies from 2.5\% to 95\%. The composition of chemical contents of Gambier depends heavily on the processing method or the handling method utilized on the Gambier leaves. Every Gambier central production region has specific and unique processing method hence each product has different chemical content. Catechin content of Gambier products from Riau Archipelago, North Sumatera, Aceh and South Sumatera varies significantly from Gambier product produced by West Sumatera. Current SNI has not represented all Gambier products manufactured by central production regions in Indonesia.

Key words: catechin, SNI, Thrope and Whiteley, Riau, North Sumatra, South Sumatera, West Sumatra, Aceh, Babel

\section{PENDAHULUAN}

Gambir adalah sari getah yang di ekstraksi dari daun tanaman gambir (Uncaria Gambier Roxb) yang dilakukan dengan berbagai cara pengolahan mulai dari pengolahan tradisional yang masih digunakan sampai saat ini maupun dengan mengunakan peralatan semi mekanis ataupun modern yang dikembangkan saat ini.

Saat ini yang selalu menjadi acuan kandungan katekin gambir adalah hasil penelitian yang dilaporkan Thorpe dan Whiteley (1921) dan SNI gambir SNI 01-3391-2000 .

Kandungan kimia utama gambir yang dilaporkan dari hasil penelitian Thorpe dan 
Whiteley (1921) adalah katekin (7-33\%) dan asam kateku tanat (20-50\%). Burkill (1935) mengacu hasil penelitian tersebut dan menguraikan kandungan lainnya selain katekin dan asam kateku tanat dengan komposisi katekin 7-33\%, asam kateku tanat 20-55\%, pyrokatekol $20-30 \%$, gambir fluoresensi $1-3 \%$, kateku merah $3-5 \%$, quersetin $2-4 \%$, fixed oil 1$2 \%$, lilin 1-2\%, dan mengandung sedikit alkaloid. Nazir (2000) serta Amos dkk (2004) juga masih berpatokan pada kandungan kimia hasil penelitian Thorpe dan Whiteley (1921) serta Burkill (1935).

Standar Nasional Indonesia - Gambir (SNI 01-3391-1994 dan revisi SNI 01-3391-2000, menguraikan hubungan kandungan katekin dengan mutu gambir, yaitu sebagai berikut mutu III kandungan katekinnya $40 \%$, mutu II besarnya $50 \%$ dan mutu I besarnya $60 \%$, SNI gambir ini berpatokan pada produk gambir yang dihasilkan dari sentra Sumatera Barat

Kandungan katekin gambir dari sentra gambir di Indonesia berbeda satu dengan lainnya yang salah satu penyebabnya adalah proses pengolahan yang berbeda dan sifat katekin yang rentan terhadap panas. Apabila katekin dipanaskan pada temperatur $110^{\circ} \mathrm{C}$ atau dengan cara memanaskan pada larutan alkali karbonat, maka akan kehilangan satu molekul air dan berubah menjadi asam kateku tanat (Thorpe,JF., and Whiteley, M.A. 1921). Katekin jika mengalami pemanasan atau pemasakan yang lama dengan larutan bersifat basa akan melakukan kondensasi sendiri sehingga berubah menjadi asam kateku tanat yang berjumlah 24\% (Leung,1980)

Heyne K (1987) Tumbuhan berguna Indonesia Jilid III, menyorot proses pengolahan gambir yang dilakukan di pesisir Malaya yang proses pengolahannya sama dengan yang dilakukan di Propinsi Kepulauan Riau. Kandungan katekin pada gambir yang dihasilkan dari pengolahan yang dilakukan di daerah ini berkisar 2,5\% sampai dengan 35\%, jadi menurut dugaan penulis bahwa gambir yang dianalisis atau diteliti oleh Thorpe dan Whiteley, Burkill dan Leung, adalah gambir yang pengolahannya sama dengan yang dilakukan saat ini di Propinsi Kepulauan Riau.

Pada pembahasan komposisi kandungan kimia gambir yang dilakukan pada penelitian ini hanya pada kandungan katekin, tidak melakukan penelitian yang lebih lanjut untuk komposisi kandungan kimia lainnya yang juga terdapat di gambir. Berdasarkan komposisi katekin yang dihasilkan peneliti sudah mendapatkan gambaran bahwa komposisi kimia gambir mempunyai batas range katekin yang berbeda dengan yang dihasilkan oleh Thorpe dan Whiteley dan SNI 01-3391-2000

Berdasarkan hasil penelitian kandungan katekin pada produk gambir yang dihasilkan di Indonesia ditemukan range kandungan katekin antara 2,5\% sampai dengan 95\%. Telah diuraikan diatas bahwa pengaruh pengolahan dan cara pengolahan gambir mengakibatkan terjadinya perubahan komposisi kandungan utama gambir yaitu katekin dan asam kateku tanat. Dalam penelitian ini hanya dilakukan perhitungan persentasi pada kandungan katekin, lalu atas dasar perhitungan ini penulis menyimpulkan terjadi perubahan komposisi pada gambir yang mengalami perbedaan dengan yang dilaporkan oleh peneliti sebelumnya.

\section{KANDUNGAN KATEKIN PADA SENTRA PRODUKSI GAMBIR DI INDONESIA}

\subsection{Daerah Istimewa Aceh}

Pengolahan gambir di Daerah Istimewa Aceh terpusat di Kabupaten Aceh Tenggara, di Kecamatan Badar yaitu desa Pulai Piku, desa Tengku Kute, dan desa Kute Ujung dengan luas areal lebih kurang $127 \mathrm{Ha}$. Pengolahan gambir di daerah ini menggunakan sistem press yang terbuat dari kayu yang sangat sederhana. Tempat unit usaha berupa pondok kerja yang sangat sederhana terbuat dari kayu dan belum tertata dengan baik sebagaimana layaknya suatu industri, akan tetapi pondok pengolahan dan alat pengolahan digunakan bersama-sama dalam satu kelompok pengolahan dengan waktu yang berbeda.

Proses pengolahan gambir di daerah ini dilaksanakan sebagai berikut (Amos dkk, 2004):

- Daun dan ranting gambir direbus selama 1 jam

- Kemudian ditumbuk dengan lesung sampai seluruh daun dan ranting menjadi hancur

- Dipanaskan lagi dan langsung dipres dengan menggunakan peralatan pres yang terbuat dari kayu

- Hasil pengepresan diendapan semalam, ditiriskan, kemudian dikeringkan dengan bantuan sinar matahari.

Hasil analisa kandungan katekin yang diperoleh $70 \%$ sampai $80 \%$

\subsection{Sumatera Utara}

Daerah penghasil gambir di Sumatera Utara banyak terdapat di Kabupaten Dairi tersebar di Kecamatan Solok (desa Tanjung Medan dan desa Kuta Tinggi), Kecamatan Si Empa Nempu 
Hulu (desa Kuta Tengah) dan Kecamatan Silima Pungga (desa Kentara). Pengolahan gambir di daerah ini menggunakan peralatan kempa dari kayu dan juga sistem hidrolik.

Sama seperti pengolahan di Daerah Istimewa Aceh, pengolahan di daerah Sumatera Utara juga melalui tahapan yang panjang dan petani hanya dapat melakukan sekali pengolahan perharinya dengan hasil 3,5 Kg/hari gambir.

Pengolahan dilakukan sebagai berikut:

- Daun dan ranting gambir yang telah dipetik, direbus lebih kurang 2 jam

- Selembar demi selembar daun gambir diperas menggunakan tangan, sehingga semua getah keluar dari air.

- Diendapkan pada bak pengendap, ditiriskan, dicetak, dan kemudian dikeringkan dengan bantuan sinar matahari.

Hasil analisa kandungan katekin yang diperoleh $70 \%-85 \%$.

\subsection{Sumatera Selatan}

Sentra produksi gambir di Sumatera Selatan adalah di Kabupaten Musi Banyuasin, Kecamatan Babat Toman, desa Toman, Pengolahan gambir di desa ini dilakukan oleh keluarga yang melibatkan semua anggota keluarga (isteri dan anak), dengan pembagian kerja yang seimbang. Proses pengolahan melalui tahapan yang panjang dan banyak menghabiskan waktu sehingga dalam satu hari hanya melakukan satu kali pengolahan. Produk gambir yang dihasilkan habis banyak dipakai sebagai campuran makan sirih.

Pengolahan gambir di daerah ini dilaksanakan sebagai berikut:

- Daun dan ranting tanaman gambir direbus lebih kurang 1 jam

- Kemudian daun dan ranting dihancurkan dengan mengunakan alat pengiling

- Daun dan ranting yang hancur dimasukan dalam wadah pengepresan yang terbuat dari rotan, selanjutnya dipanaskan sebentar

- Dipress dengan hidrolik kekuatan tekanan sebesar 2 ton

- Diendapkan

- Dimasukan dalam cetakan yang terbuat dari kayu persegi dan dipotong-potong dengan ukuran $1 \times 1 \times 6 \mathrm{~cm}$

- Dikeringkan dengan cara penjemuran

Anaslisa kandungan katekin yang dihasilkan dari cara pengolahan ini adalah 70\% - 95\%.

\subsection{Bangka Belitung}

Pusat produksi gambir berlokasi di Kabupaten Sungai Liat, pengolahan gambir di daerah ini dilakukan oleh keluarga yang melibatkan pekerja perempuan. Pengolahan masih dilakukan dengan peralatan dan cara yang sederhana, menghabiskan banyak waktu dalam satu proses sehingga petani hanya dapat melakukan satu kali pengolahan dalam satu hari. Semua produk yang dihasilkan habis dipasaran lokal dan dimanfaatkan campuran makan sirih.

Pelaksanaan pengolahan gambir di daerah ini dilakukan sebagai berikut:

- Daun dan ranting tanaman gambir direbus lebih kurang 1 jam

- Kemudian daun dan ranting dihancurkan dengan penumbukan

- Daun dan ranting yang hancur dimasukan dalam wadah pengepresan yang terbuat dari rotan, selanjutnya dipanaskan sebentar

- Dipress dengan menggunakan balok bertumpu pada kekuatan pengepres

- Diendapkan

- Dicetak dengan ukuran 1 × 4 ×4 cm

- Dikeringkan dengan cara penjemuran

Hasil analisa kandungan katekin yang dihasilkan antara $70 \%$ sampai dengan $80 \%$

\subsection{Sumatera Barat}

Sentra produksi gambir di Sumatera Barat terbanyak dibandingkan dengan daerah lainnya, dan menghasilkan gambir untuk kebutuhan ekspor. Industri pengolahan gambir di daerah ini terdapat di Kabupaten Lima Puluh Kota, Kabupaten Pesisir Selatan, Kabupaten Pesaman, Kabupaten Sawah Lunto, Kabupaten Sijunjung, Kabupaten Tanah Datar, dan Kota Madya Bukit Tinggi.

Sebagian besar pengolahan gambir di Sumatera Barat masih dilakukan secara tradisional, sebagian kecil telah melakukan pengolahan secara modern.

Tahapan-tahapan pengolahan Gambir tradisional dilakukan sebagai berikut:

- Daun bersama rantingnya dimasukkan kedalam keranjang rotan, lalu dipadat dengan cara menginjak-injak sampai seberat 40-50 kg.

- Kemudian diteruskan dengan memasak air pada kanca sebanyak 40-60 liter.

- Setelah air panas baru dimasukkan ke dalam keranjang rotan yang telah diisi dengan daun, lalu direbus selama lebih kurang 1,5 jam. 
- Daun yang sudah direbus dikeluarkan, kemudian dililit/dibundarkan dengan tali pelilit sampai berbentuk bola dengan lingkaran lebih kurang 1 (satu) meter. Kemudian ujung pangkal dipukul sampai lempeng, agar nanti dalam apitan tidak berputar.

- Bundalan daun dimasukkan kedalam apitan lalu dikempa. Cairan ekstraksi di tampung

- Pagi harinya getah gambir dicetak.

- Hasil cetakan seterusnya dikeringkan dengan panas matahari atau diletakkan pada tempat diatas tempat merebus daun.

Tahap-tahap pengolahan secara modernisasi umumnya sama dengan cara yang diatas, hanya yang dimodernisasi adalah pada tahapan nomor 5 dimana diganti dengan pengepresan mengunakan tenaga hidrolik. Analisa kandungan katekin antara 40\% sampai dengan $80 \%$.

\subsection{Propinsi Riau}

Sentra produksi gambir di Propinsi Riau terletak di kecamatan XII Koto Kampar. Peralatan dan pengolahan gambir di daerah ini hampir sama dengan yang alat dan proses pengolahan yang digunakan di daerah Sumatera Barat. Kandungan katekin yang diperoleh $50 \%-70 \%$.

\subsection{Kepulauan Riau}

Sentra produksi gambir di Propinsi Kepulauan Riau ada di Pulau Kundur dan daerah Kepulauan Dabo Singkep. Produk gambir yang dihasilkan di daerah ini dilakukan dengan 2 (dua) cara pengolahan yang berbeda prosesnya, sehingga kandungan katekin pada produk gambir tersebut juga berbeda.

Proses pengolahan pertama dilakukan sebagai berikut:

- Daun dan ranting yang telah dipetik dikumpulkan pada tempat perebusan, daun dan ranting dipotong-potong selanjutnya direbus dalam kancah (kuali), perebusan dilakukan sambil mengaduk-aduk daun dan ranting. (lamanya perebusan \pm 4 jam)

- Daun dan ranting diangkat dari kuali dan perebusan diteruskan sampai air rebusan (hasil ekstraksi) menjadi kental.

- Hasil perebusan dituang ke dalam ember plastik, 30 menit kemudian diaduk hingga hasil ekstraksi mencapai suhu kamar.

- Dimasukkan dalam cetakan yang berbentuk segiempat besar terbuat dari papan balok dan diendapkan selama 1 malam
- Keesokannya cetakan dibuka dan dipotongpotong sesuai dengan ukuran yang diinginkan konsumen.

- Ekstrak gambir diletakkan dalam tampi yang terbuat dari rotan, dimasukkan dalam ruangan pengering dan dikeringkan dengan cara mengalirkan udara panas yang didapat dari pembakaran kayu ke dalam ruangan pengering.

- Setelah 14 hari produk gambir siap dipasarkan.

Proses pengolahan kedua dilakukan sebagai berikut:

- Daun dan ranting yang telah dipetik dikumpulkan pada tempat perebusan, daun dan ranting dipotong-potong selanjutnya direbus dalam kancah (kuali), perebusan dilakukan sambil mengaduk-aduk daun dan ranting. (lamanya perebusan \pm 2 jam)

- Daun dan ranting diangkat dari kuali dan perebusan diteruskan sampai air rebusan (hasil ekstraksi) menjadi kental.

- Hasil perebusan dituang ke dalam ember plastik, 30 menit kemudian diaduk hingga hasil ekstraksi mencapai suhu kamar.

- Dimasukkan dalam cetakan yang berbentuk segi empat besar terbuat dari papan balok dan diendapkan selama 1 malam

- Keesokannya cetakan dibuka dan dipotongpotong sesuai dengan ukuran yang diinginkan konsumen.

- Ekstrak gambir diletakkan dalam tampi yang terbuat dari rotan, dimasukkan dalam ruangan pengering dan dikeringkan dengan cara mengalirkan udara panas yang didapat dari pembakaran kayu ke dalam ruangan pengering.

- Setelah 14 hari produk gambir siap dipasarkan.

Bentuk dan warna kedua produk yang dihasilkan dari pengolahan pertama menghasilkan gambir dengan warna hitam bagian luar maupun bagian dalam dengan bau yang khas. Produk gambir dari pengolahan cara kedua menghasilkan gambir yang luarnya berwarna hitam akan tetapi di dalamnya merah bata.

Hasil analisis kandungan katekin cara pengolahan pertama $2,5 \%$ sampai dengan $12,5 \%$, sedangkan cara pengolahan kedua menghasilkan katekin 25\% sampai dengan 35\%. 


\section{HASIL DAN PEMBAHASAN}

Tabel di bawah ini memaparkan kandungan katekin hasil penelitin produk gambir di Indonesia dan katekin hasil penelitian Thrope, JF dan SNI gambir Indonesia.

Tabel 1 Hasil Analisa Kandungan Katekin di Sentra Produksi di Indonesia

\begin{tabular}{|l|l|c|}
\hline No. & \multicolumn{1}{|c|}{ Sentral Produksi } & $\begin{array}{c}\text { Kadar katekin } \\
\text { (\%) berat bobot }\end{array}$ \\
\hline $\mathbf{1}$ & Daerah Istimewa Aceh & $70-80$ \\
\hline $\mathbf{2}$ & Sumatera Utara & $70-85$ \\
\hline $\mathbf{3}$ & Sumatera Selatan & $70-95$ \\
\hline $\mathbf{4}$ & Babel & $70-80$ \\
\hline $\mathbf{5}$ & Sumatera Barat & $40-80$ \\
\hline $\mathbf{6}$ & Riau & $50-70$ \\
\hline $\mathbf{7}$ & Kepulauan Riau & $2,5-12,5$ \\
& & $25-35$ \\
\hline
\end{tabular}

Tabel 2 Hasil Penelitian Thrope,JF and Whiteley, MA dan SNI (01-3991-2000)

\begin{tabular}{|l|l|c|}
\hline No. & \multicolumn{1}{|c|}{ Standar } & $\begin{array}{c}\text { Kadar Katekin } \\
\text { (\%) berat bobot }\end{array}$ \\
\hline $\mathbf{1}$ & $\begin{array}{l}\text { Thrope,JF., and } \\
\text { Whiteley, M.A., }\end{array}$ & $7-33$ \\
\hline $\mathbf{2}$ & $\begin{array}{l}\text { SNI gambir (01-3991- } \\
\text { 2000) }\end{array}$ & $40-60$ \\
\hline
\end{tabular}

\subsection{Aceh, Sumatera Utara, Sumatera Selatan} dan Babel

Aceh, Sumatera Utara, Sumatera Selatan, dan Babel, kandungan katekin yang didapatkan antara $70 \%$ sampai 95\%. Kandungan katekin yang diperoleh berbeda dengan yang dilaporkan oleh Thorpe and Whiteley (1921) dan SNI 013991-2000 Perbedaaan disebabkan proses pengolahan yang berbeda terhadap produk gambir yang dihasilkan. Karena sifat ketekin yang akan kehilangan 1 molekul air pada saat pemanasan di atas $110^{\circ} \mathrm{C}$ menjadi asam kateku tanat sehingga perlakuaan proses yang pemasanaanya tidak sampai $110^{\circ} \mathrm{C}$ kandungan katekin yang dihasilkan akan lebih tinggi. Proses pengolahan gambir di sentral Aceh, Sumatera Utara, Sumatera Selatan dan Babel proses pemanasannya tidak mencapai suhu $110^{\circ} \mathrm{C}$ atau tidak terlalu lama dipanaskan pada suhu $110^{\circ} \mathrm{C}$ sehingga kandungan katekinnya cukup tinggi dan berkisar 70\% - 90\%.

Kandungan katekin dari sentral produk di Sumatera Barat sebesar 40\% - 80\%, kandungan katekin $80 \%$ adalah pesanan khusus dari konsumen, sebagaian besar produk gambir yang dihasilkan kandungan katekinnya 40\% - $60 \%$. Produk yang dihasilkan dari sentral produksi gambir di Sumatera Barat sampai dengan tahun 2000 selalu menjadi acuan bagi SNI. Hasil kandungan katekin berbeda dengan yang dilaporkan oleh Thorpe and Whiteley (1921), sekali lagi menunjukkan bahwa hasil penelitian Thorpe and Whiteley tidak bisa digunakan sebagai acuan yang umum untuk seluruh produk gambir yang dihasilkan. Hal ini disebabkan perbedaan perlakukan pengolahan. (Thorpe and Whiteley, 1921)

\subsection{Kepulauan Riau}

Hasil analisa kandungan katekin gambir yang diproduksi di kepulauan riau 2,5 - 12,5\% dan $25 \%-35 \%$, perbedaaan diantara keduanya disebabkan cara pengolahan dan perlakukan yang berbeda terhadap gambir, pengaruh suhu dan lama perebusan sangat menpengaruhi kandungan katekin pada produk gambir (Thrope,JF., and Whiteley, M.A., 1921).

Kandungan katekin yang dihasilkan dengan cara pengolahan ini hampir sama seperti yang dilaporkan oleh Thorpe,JF., and Whiteley, M.A. (1921). Jadi diperkirakan bahwa gambir yang diamati dan dianalisis oleh Thorpe,JF., and Whiteley cara pengolahannya hampir sama dengan yang dihasilkan dari Propinsi Kepulauan Riau

\subsection{Sumatera Barat dan Riau}

Kandungan katekin dan di hasilkan dari produk gambir di Sumatera barat hampir sama dengan kandungan katekin yang dihasilkan di Propinsi Riau. Peneliti menemukan cara pengolahan dan peralatan yang digunakan hampir sama begitu juga dengan kondisi tanahnya sehingga kandungan produk gambir yang dihasilkan juga hampir sama, produk gambir Sumatera Barat kandungan katekinnya $40 \%-80 \%$ dan Riau $50 \%$ - 70\%. Produk gambir Sumatera barat sampai saat ini menjadi patokan SNI gambir Indonesia.

\section{KESIMPULAN}

Kandungan katekin yang dilaporkan oleh Thorpe,JF., and Whiteley, M.A. (1921) dan SNI gambir Indonesia, tidak bisa lagi mewakili atau dijadikan sebagai patokan terhadap gambir secara umum, karena kandungan katekin pada produk gambir yang dihasilkan di Indonesia sangat bervariasi dari 2,5 sampai dengan 95\%. 
Produk gambir yang diamati atau di analisis oleh Thorpe, JF., and Whiteley, M.A. (1921) adalah produk gambir yang diambil dari daerah semenanjung Malaya yang diperkirakan oleh peneliti bahwa proses pengolahannya sampai saat ini masih dilakukan di Propinsi Kepulauan Riau. Produk gambir dari sentral produksi sumatera barat sampai saat ini menjadi patokan SNI gambir Indonesia

Setiap perlakuan dan proses yang berbeda pada daun dan ranting gambir sangat mempengaruhi kandungan katekin pada gambir. Jadi sebaiknya perlu dilakukan peninjauan ulang terhadap standar kandungan katekin terhadap SNI yang masih berlaku sampai saat ini.

\section{DAFTAR PUSTAKA}

Aisman, Novizar. (1999), Kajian Sosio-TeknoEkonomi Komoditi Gambir Sumatera Barat (Studi Kasus: Desa BarungBarung Belantai, Pesisir Selatan). Fakultas Pertanian Unand. hal 18

AKGI Sumbar. (1997), Prospek dan Permasalahan Ekspor Gambir. Makalah dalam rangka Penyuluhan Peningkatan Bokor Gambir di Padang 23-24 Juni 1997, hal 22

Amos. (1992), Perbandingan Efektifitas Peralatan Prototipe Ulir Pengolahan Gambir BPPT dengan Peralatan Pengolahan Gambir secara Tradisional di Sumatera Barat.

Amos. (1995), Pengkajian Pengolahan Gambir Menggunakan Pelarut Alkohol, Majalah BPPT, No. LXVII/ 1995. BPPT. Jakarta

Amos. (1995.), Pengembangan Peralatan Pengolahan Gambir di Desa Lubuk Alai Sumatera Barat, Prosiding Dialog Teknologi dan Industri, BPPT

Amos. (1996), Pengkajian Proses Pengolahan Gambir di Kec. Kundur - Riau. Majalah BPPT, Jakarta

Amos, Bayu Rusmandana, Agus Triputranto, dan Irshan Zainuddin. (1998), Aplikasi Alat Pengolahan Gambir. Laporan Kegiatan BPPT, Jakarta

Amos, Irshan Zainuddin dan Suharto Ngudiwaluyo, (1996), Modifikasi Peralatan Pengolahan Gambir di Desa Siguntur, Sumatera Barat. Majalah IImiah Analisis Sistem Nomor 7, Tahun III, Jakarta

Amos, Irshan Z dan Bambang H. (1995), Pengembangan Alat Pengolahan Gambir di Sumatera Barat, Agrotek Vol2, Nomor 2, Institut Pertanian Bogor, Bogor.
Amril. (1997), Proses dan Penerapan Teknologi Pengolahan Gambir. Kantor Wilayah Departemen Perindustrian dan Perdagangan Propinsi Sumatera Barat. (tidak dipublikasi). 15 hal.

Anonim. (1998), Tak Melulu untuk Penyirih. Trubus Tahun XXIX, Desember, Hal 75

Anonim. (1985), Departemen Perdagangan: Standar Perdagangan dan Standar Metoda Pengujian Gambir. SP-SMP-1976 (Revisi Pebuari 1985) Pusat Pengujian Mutu Barang. Jakarta

Ansyarullah dan Z.Hasan. (1994), Pengaruh Jarak Tanaman Terhadap Pertumbuhan Gambir (Uncaria Gambier Roxb) Prosiding Seminar Penelitian Tanaman Rempah dan Obat Sub Balitro Solok. No.04-1994. Hal 1-7

Asis,I. (1999), Pengaruh Penundaan Waktu Olah dan Penambahan Air Penirisan Terhadap Mutu dan Rendemen Gambir. Skripsi Fakultas Pertanian Unand. Padang. Tidak Dipublikasi

Azima,F. M.H.Abbas., Harizal. (1995), Prospek Peningkatan Mutu Gambir Melalui Cara Pengolahan yang dilakukan Petani. Prosiding Seminar Nasional Agro Industri menuju Tahun 2020. Fakultas PertanianPerhepi Sumatera Barat

Bakhtiar, A. (1991), Manfaat Tanaman Gambir. Makalah Penataran Petani dan Pedagang Pengumpul Gambir di Kecamatan Pangkalan Kab. 50 Kota. 29-30 November 1991. FMIPA Unand. Padang, hal 23

Balitbang Industri Padang. (1994), Perbaikan Proses dan Pembuatan Prototype Alat Kempa Pengolahan Gambir. Media Komunikasi No.16 Balitbang Industri Padang, hal 17

Balitbang Industri Padang. (1995), Modifikasi Alat Pengering Gambir. Media Komunikasi No.26 Balitbang Industri Padang, hal 17

Baranowski,J.D. and Nagel C.W. (1981), Isolation of l-epicatechin and d-catechin by column chromatograpy. J.of Agric. Food Chem. Jan/Feb, pp. 63-67

BIP Sumbar. (1994), Pemupukan dan Pengolahan Gambir, hal 40

Burkill,I.H. (1966), Dictionary of the Economic Product of Malay Peninsula, Vol II. Government of Malaysia and ingapore. Kuala Lumpur, pp 2196-2204

Cockburn,J.G., Bird,J. (1921), Dictionary of Applied Chemistry. John Wiley \& Sons Inc. New York 
Daswir.,I.Kusuma. (1993), Sistem Usaha tani Gambir di Sumatera Barat. Media Komunikasi Penelitian dan Pengembangan Tanaman Industri. No.11, Februari, hal. 68-74

Daud,D. (1993), Pengaruh Umur Daun dan Waktu Penyarian terhadap rendemen dan Mutu Gambir (Uncaria gambir) yang di hasilkan. Dinamika Penelitian BIPA Vol.3, No. 6: 29-35

Heyne. (1987), Tumbuhan Berguna Indonesia III. Badan Penelitian Pengembangan Kehutanan, Departemen Kehutanan. Jakarta

Irshan Zainuddin. (1995), Pengembangan Peralatan Pengolah Gambir dalam Upaya peningkatan Produksi Gambir di Sumatera Barat. Laporan Interen Direktorat Pengkajian Ilmu Teknik, BPPT. Jakarta

Irshan Zainuddin. (1996), Ujicoba Pengolahan Gambir dengan mengunakan Kempa Ulir di Sumatera Barat, Majalah BPPT. Edisi No: LXXVII

Irshan Zainuddin, Amos. (1994), Teknologi Pengolahan Gambir di Sumatera Barat (Studi Kasus di desa Lubuk Alai Kabupaten 50 Kota. Prosiding Presentasi
Ilmiah Peneliti BPP Teknologi ke XXV. BPPT. Jakarta

Irshan Zainuddin, Bayu Rusmandana, Amos. (1995), Pengembangan Peralatan Pengolah Gambir dalam Rangka Pendayagunaan Sumberdaya Manusia petani Pengolah Gambir. Disajikan dalam seminar daerah Peranan Iptek dalam rangka Meningkatkan Kualitas Hidup Sosial Ekonomi Masyarakat dan Pengembangan Potensi Daerah di Padang, 12 Oktober

M. Jusuf Djafar, Wahyu Purwanto. (1992), Pengolahan Gambir di Sumatera Barat Prospek dan Permasalahannya. Laporan Interen Direktorat Pengkajian IImu Teknik. BPPT. Jakarta

Thorpe,J.F, and Whiteley,MA. (1921), Thorpe's Dictionary of Applied Chemistry.

Trease,G.F. (1922), A Texbook of Pharmacognose. Bailliare, Trindall and Cassel. London

Van Hulssen,C.J. and Koolhaas,D.R. (1939), Die Bestimung von Catechin und CatechinGergstoff in Gambir. Rec. Travaux. Chim. Phys. Bes. 58 (718). pp 831-839 